\title{
Labour Lines and Colonial Power: Indigenous and Pacific Islander Labour Mobility in Australia
}

Edited by Victoria Stead and Jon Altman. Canberra, ANU Press, 2019. xviii + 312 pp., illustrations, notes, maps. ISBN 9781760463069 (pbk), 9781760463076 (ebook). AU\$55.00 (pbk).

\section{Nicholas Hoare}

To cite this article: Nicholas Hoare (2020): Labour Lines and Colonial Power: Indigenous and Pacific Islander Labour Mobility in Australia, The Journal of Pacific History, DOI: 10.1080/00223344.2020.1726476

To link to this article: https://doi.org/10.1080/00223344.2020.1726476

$$
\text { 册 Published online: } 27 \text { Feb } 2020 .
$$

Submit your article to this journal ๘

Џ Article views: 24

Q View related articles $\sqsubset$

View Crossmark data \lceil 


\section{Book Review}

Labour Lines and Colonial Power: Indigenous and Pacific Islander Labour Mobility in Australia. Edited by Victoria Stead and Jon Altman. Canberra, ANU Press, 2019. xviii + 312 pp., illustrations, notes, maps. ISBN 9781760463069 (pbk), 9781760463076 (ebook). AU\$55.00 (pbk).

If social media attention is to be taken as a reliable measure of popularity - and we know this is increasingly assumed to be the case - then Labour Lines and Colonial Power has already made a significant impact on the field of Pacific Studies. Indeed, the timing of its August 2019 release could not have been better. In the eyes of many, the Australian Government had just disgraced itself at the Pacific Islands Forum in Tuvalu, refusing to take responsibility for the existential threat of climate change in the region. To make matters worse, back in Australia, Deputy Prime Minister Michael McCormack publicly dismissed Pacific Islander concerns about climate change, saying 'they'll continue to survive because many of their workers come here and pick our fruit'. McCormack would later apologize for this reference to the Seasonal Worker Programme (SWP), but not before one social media commentator asked that he be sent a copy of the book. For editors Victoria Stead and Jon Altman, and the team at ANU Press, they could not have hoped for a greater validation of their labour in producing this timely and important intervention into Australian political debate.

While the collection itself stems from a June 2017 Deakin University workshop, many of the ideas expressed within can be traced to a host of important conversations during recent conferences, symposia and workshops often revolving around Tracey Banivanua Mar and her trailblazing scholarship on the intersections of labour, race and Indigeneity in the colonial Pacific and Australia. Thus, as much as this collection is a timely response to the Australian Government's head-in-the-sand policy approach, it is also a fitting tribute to Banivanua Mar whose posthumous chapter on 'Boyd's Blacks' - the 200-odd Ni-Vanuatu brought to work at Boydtown, NSW in the 1840s - gives readers a final chance to access her 'new and fresh insights' as Lynette Russell graciously points out in her afterword (p. 310). That Banivanua Mar's chapter is surrounded by those of her friends, colleagues, and students - who so readily engage with and cite her scholarship - is further testament to her agenda-setting ability within the disciplines of History and Pacific Studies.

In what cannot have been an accident, the volume starts and ends in Indigenous Australia. There is a neat symmetry to the book in general with Victoria Stead's incisive chapter, 'Money Trees, Development Dreams and Colonial Legacies', acting as a fulcrum between the historical and contemporary chapters. It is here where the volume's interdisciplinary aims are most immediately realized, with Stead's analysis of the SWP successfully marrying historical and contemporary perspectives in both a constructive and non-reductive fashion. After expertly dissecting the historiographical problem of agency in the Pacific labour trade, Stead moves past an older generation of Pacific historians, once intent on emphasizing the freedom of Pacific Island agents, to instead insist that we ask 'why European goods were so sought after' and how ideas of colonial developmentalism created, and continue to create, such a demand for foreign employment (p. 141). 'This', she adds, 'is to attend both historically and anthropologically to the intersection of coloniality and Pasifika agency' (p.141), and by attending to both, Stead is able to refute Stephen Howes' celebratory portrayal of the SWP which he drew from overwhelmingly positive 2015 World Bank survey data (p. 151).

Based, therefore, on this intersection between Aníbal Quijano's concept of the 'coloniality of power' and Pasifika or Indigenous agency, Labour Lines and Colonial Power succeeds in amassing a compelling amount of evidence to illustrate that even though Australia's individual and/or collective attitudes towards 'coloured' or colonized labour have always been developed on 'white' or settler terms, Indigenous and Pasifika communities have been remarkably adept 
at navigating or re-negotiating these terms, however unequal, towards their own ends. To be clear, the answer to the 'developmental paradigms' (p. 154) foisted upon 'developing peoples' by decades of colonial and neo-colonial public policy does not lie in unfettered labour mobility. However, as many of the contributors to this volume point out, mobility can play a legitimate and important role in the lives of many Indigenous and Pasifika individuals looking to serve their communities. Whether we are referring to 19th-century Kāi Tahu who travelled to Australia for reasons related to mana (chapter five) or 21 st-century trans-Tasman Pasifika migrants who move to Brisbane for 'a good and happy life' (p. 185), successful experiences of mobility rarely follow the predetermined paths imagined by top-down policy interventions (as the reverse examples highlighted by Stead (chapter six) and Makiko Nishitani and Helen Lee (chapter seven) in relation to the SWP so powerfully show).

Jon Altman's searing final chapter on the Community Development Employment Projects scheme and its successor, the Community Development Program, introduced into western Arnhem Land in 2015 perfectly summarizes the gaping hole between policy design and implementation in Australia's contemporary Indigenous policy. Altman describes that in order to reduce the number of Indigenous Australians on 'sit down' money (welfare), the reconstituted Bawinanga Aboriginal Corporation introduced a raft of development projects to 'impose Western forms of labouring on Kuninjku' (p. 293). In what Altman states was 'just an imagined procedural fix based on ideological blind faith that has no basis in regional reality' (p. 302), pizza ovens, market gardens and chicken coops were introduced 'to replace "unhygienic" open fires and ground ovens' (p. 292). And a once-comfortable local economy based on seasonal hunting and gathering where Altman's research participants might report being far 'too busy for a full-time Balanda [Western] job' (p. 298) was changed to the point that during a 2017 return visit, Altman found the pizza oven 'still there, in sound condition and still unused', though the small community at Mumeka he had been visiting since the 1970s had all but gone, 'scattered' across the region (p. 303).

As far as enduring imagery goes, Altman's unused pizza oven is hard to go past. As a way of dealing with the evident frustration accompanying decades of fieldwork for seemingly little in the way of positive outcomes, one can understand the urge - the need - to turn to black humour in response. Historians, too, are no less susceptible to the ironic mode, and I would kick myself if I finished this review without making mention of the ironic twists of fate that met the kidnapping explorer D.W. Carnegie, killed by a poisonous arrow in Nigeria (chapter two), and the labour trader Benjamin Boyd who went missing in the Solomon Islands in the process of setting up his own Pacific Islands confederation (chapter three). While there is much more one could say about this fine volume, perhaps the pained anthropologist, doomed by proximity to never realize the long-run import of their work, can draw strength from the knowledge that future historians, armed with the benefit of hindsight, will doubtless offer some degree of catharsis such as Shino Konishi and Banivanua Mar were able to do here. For an interdisciplinary book intent on complicating and traversing the distinctions between past and the present, Indigenous and migrant, legality and illegality, Labour Lines and Colonial Power should offer a cogent model for similar studies by critical Pacific Studies scholars based in other settler-colonial societies like Aotearoa New Zealand, Hawai'i and Kanaky/New Caledonia.

NICHOLAS HOARE

The Australian National University nicholas.hoare@anu.edu.au

(C) 2020 Nicholas Hoare https://doi.org/10.1080/00223344.2020.1726476 